\title{
Whole body vibration in operators using agricultural soil preparation equipment
}

\author{
Viviane Castro dos Santos $^{1 *}$ (iD Leonardo de Almeida Monteiro ${ }^{1}$ iD \\ Deivielison Ximenes Siqueira Macedo ${ }^{1}$ (D) Enio Costa ${ }^{2}$ (D)
}

\begin{abstract}
${ }^{1}$ Departamento de Engenharia Agrícola, Universidade Federal do Ceará (UFC), Campus do Pici, 60356-001, Fortaleza, CE, Brasil. E-mail: viviane.castro@ufc.br. "Corresponding author.

${ }^{2}$ Instituto Federal de Educação, Ciência e Tecnologia do Ceará, Campus Fortaleza, Fortaleza, CE, Brasil.

ABSTRACT: Agricultural tractors have been reported to exert negative effects on operator health. It is well known that when a farm machine is designed it must consider the human factors, to raise the safety levels and work quality. The aim of the present study was to estimate the degree of vibration transmissibility from the agricultural equipment used for the periodic soil preparation process and determine the exposure of the whole body of the operator to the vibration, incident to the agricultural tractor during the operation. A 4x 2 TDA tractor was employed, coupled to the periodic soil preparation equipment. Five sets were used (tractor-disk plough, tractor-moldboard plow, tractor-offset disc harrow, tractor-rotary hoe, and tractor-scarifier) and the tractor without the equipment being coupled, at two tractor speeds of displacement (3.5 km. $h^{-1}$ and $\left.6.1 \mathrm{~km} . \mathrm{h}^{-1}\right)$. An index (IAVEA) was developed to assess whether the amplification or attenuation of the vibrations takes place on each orthogonal axis. The data were processed using the Noise Studio ${ }^{\circledR}$ software 6.95. Statistical evaluation was performed using the ASSISTAT version 7.7 beta program. After normality, the data were submitted to the analysis of variance by the F test; when significance was reported, the means were compared using the Tukey test, at 5\% significance. The disk plow was the equipment that showed the greatest intensification of the vibrations in all the parameters estimated. All the sets assessed revealed statistically equal or higher values in terms of the tractor without the attached equipment. The IAVEA\% was an index that enabled the quantification of the amplification or attenuation caused by the use of the agricultural equipment.

Key words: ergonomics, agricultural machinery, vibrations.
\end{abstract}

Alteração na vibração de corpo inteiro em operadores pela utilização de equipamentos agrícolas de preparo do solo

RESUMO: A utilização de tratores agrícolas tem causado efeitos negativos na saúde do operador. Faz-se necessário que no projeto de uma máquina agrícola sejam levados em consideração fatores humanos, para aumentar a segurança e melhorar a qualidade de trabalho. O objetivo do presente trabalho foi avaliar a transmissibilidade da vibração em equipamentos agrícolas de preparo periódico do solo devido a exposição a vibração de corpo inteiro incidente ao operador de trator agrícola durante a operação. O trator utilizado foi um trator $4 x 2$ TDA acoplado a equipamentos de preparo periódico do solo. Foram utilizados cinco conjuntos (trator-arado de disco, trator-arado de aiveca, trator-grade off-set, trator-enxada rotativa, trator-escarificador) e um trator sem equipamento acoplado, em duas velocidades de deslocamento do trator $\left(3,5 \mathrm{~km} \cdot \mathrm{h}^{-1}\right.$ e $\left.6,1 \mathrm{~km} \cdot \mathrm{h}^{-1}\right)$. Foi desenvolvido um índice (IAVEA) para avaliar se ocorre amplificação ou atenuação das vibrações em cada eixo ortogonal. Os dados foram processados no software Noise Studio ${ }^{\circledR}$ 6.95. Para avaliação estatística foi utilizado o programa ASSISTAT versão 7.7 beta. Comprovada a normalidade, os dados foram submetidos à análise de variância pelo teste $F$ e, quando significativas, as médias foram comparadas pelo teste de Tukey a $5 \%$ de significância. $O$ arado de disco foi o equipamento que apresentou maior intensificação das vibrações em todos os parâmetros avaliados. Todos os conjuntos avaliados apresentam valores estatisticamente iguais ou superiores em relação ao trator sem equipamento acoplado. O IAVEA\% se mostrou um índice capaz de quantificar a amplificação ou atenuação proporcionada pelo uso de equipamentos agricolas.

Palavras-chave: ergonomia, máquinas agrícolas, vibrações.

\section{INTRODUCTION}

BAESSO et al. (2015) emphasized that agricultural mechanization is vital to agricultural development, as it enhances the production and increases the productivity indexes, as well as enables faster work speed and greater area of work, thus permitting the exploration of larger areas and higher uniformity of work. Productive efficiency of the operator is a significant factor in this development.

SANDI et al. (2016) purported that one of the variables that influences the productive 
performance of the operators the most, and the one which can induce a variety of health issues, is the vibration produced by tractor operation. According to Palmer et al. (2008) occupational exposure to whole body vibration is a common occurrence in populations utilizing self-propelled vehicles.

The response of the human body to vibration is influenced by physical factors such as the duration, frequency, intensity and direction of the mechanical vibration. Even if a single factor crosses the optimal level, the operator is already exposed to health risks (ZEHSAZ et al., 2011).

One of the results of the exposure of the operator to whole body vibrations is the occurrence of spine-related pathologies, which greatly impair the quality of the work activities, absence from work and severe damage to operator health (FIGUEIREDO et al. 2016).

SANDI et al. (2018) proposed that a large part of the vibration-related health problems could be circumvented by collecting the data on the working conditions and adopting the threshold values to arrive at the exposure levels.

Langer et al. (2012) stated that different strategies reveal the potential to minimize the operator's exposure to whole body vibration, suspension systems, operator education and/or improved area planning. However, it is crucial to first identify the axes at which these vibrations occur, the health risks they impose and the forms of work that are less detrimental to health.

According to SCARLET et al. (2007) the vibration intensity is directly related to the operation process being performed and to the agricultural equipment coupled to the tractor that is doing it; however, many tests are done which assess only the agricultural tractor, and the equipment coupled to it can exert sufficient damage to the operator's health.

The present research aimed to assess the transmissibility of the vibrations in the agricultural equipment used for periodic soil preparation, as the whole body is exposed to vibration incident to the agricultural tractor operator during the operation process.

\section{MATERIALS AND METHODS}

The experiment was performed in an experimental region utilized for conventional planting systems, which lacked vegetation cover material on the surface, and showed a slightly wavy flat relief. The area was characterized by its red-yellow Argisol, belonging to the sandy loam textural class, with approximately $829 \mathrm{~g} \mathrm{~kg}^{-1}$ of sand, $106 \mathrm{~g} \mathrm{~kg}^{-1}$ of clay and $65 \mathrm{~g} \mathrm{~kg}^{-1}$ of silt (MACEDO et al. 2016).
In this study, we used a platformed tractor with the original factory seat. The seat was provided with an upper backrest and armrest, and the damping system functioned through the seat upholstery and a spring-damping system.

The tractor used in this research was a $4 \times 2$ TDA with $91.9 \mathrm{~kW}$ nominal engine power, 4 cylinders, and a $4,400 \mathrm{~cm}^{3}$ total displacement. Radial tires were used, type R1, 14.9R-24 tires for the front axle, with $68.9 \mathrm{kPa}$ pressure and rear tires $18.4 \mathrm{R}$ 34 , with $82.7 \mathrm{kPa}$ pressure. Engine speed was fixed at 1,860 $\mathrm{rpm}$, where the L1 $\left(3.4 \mathrm{~km} \cdot \mathrm{h}^{-1}\right)$ and L3 (6.1 $\left.\mathrm{km} \cdot \mathrm{h}^{-1}\right)$ marches were selected, always with the multitorque button on the turtle.

With the engine speed fixed at 1,860 rpm, we chose the L1 (3.4 km.h $\left.{ }^{-1}\right)$ and L3 (6.1 $\left.\mathrm{km} . \mathrm{h}^{-1}\right)$ marches, always keeping the multi-torque button on the turtle.

The weight / power ratio was established based on the need of the equipment, so that using the same relation all the operations could be performed in an appropriate manner, to be able to make a comparison of the equipment. The tractor revealed a total mass of $6,370 \mathrm{~kg}$, giving a mass / power ratio of $69.3 \mathrm{~kg}$. $\mathrm{kW}^{-1}$, distributed as $40 \%$ on the front axle and $60 \%$ on the rear axle. On the tractor, only solid weights were used, but no liquid weights. Therefore, in order to check the correctness of the adequacy, the skating of the wheelsets was evaluated. According to ASAE EP 496.2 (1999) for sandy soils, values between 13 to $18 \%$ indicated the ideal skating. All values obtained in this study fell within the ideal skating range, revealing that suitability selected is perfect for all operations.

All the agricultural equipment employed in this study, prepared the soil up to $150 \mathrm{~mm}$ depth, to ensure equivalent conditions that would warrant making comparisons between the equipment. This confirmed that all the parameters were unified for all the treatments, the engine rotation, speed of displacement, ballasting and depth, to make certain that the only difference between treatments was the coupled equipment. When different work depths were used, the result could be affected because of the tendency for the tensile effort to increase as the depth was increased; as any increase in the effort of the traction could affect the vibrations, it is necessary to unify the depth in order to make the comparison possible. Besides, it must be noted that all the equipment used included no restrictions from the manufacturer or the literature to utilize them to the depth that was used. Another factor used to fix the depth was the weight / power ratio. This is because 
if the depth were to be increased, more ballast would be needed to maintain the skating at the ideal levels, which could in turn affect vibration. The reversible, three-disk plough was used, having $711.2 \mathrm{~mm}$ disks, $1,000 \mathrm{~mm}$ working width and $925 \mathrm{~kg}$ mass. The weight of the moldboard plow was $428 \mathrm{~kg}$, having three bodies of fixed movement, mounted onto the system of the hydraulic lift of the tractor, with angular cutouts and trunks of general use. The double-action, offset disc harrow lightweight had a 2,500 mm working width, with smooth and cut disks. Each disk is $520 \mathrm{~mm}$ in diameter, with $180 \mathrm{~mm}$ disk spacing and disk mask of $32 \mathrm{~kg}$. A rotary hoe having 800 $\mathrm{mm}$ working width was provided with six blades per flange, three on each side of the mounted equipment.

Tests were conducted adhering to the guidelines established by the NHO-09 (Occupational Exposure to Whole Body Vibration) standard (FUNDACENTRO, 2013), as well as to the Annex A (Field measurements) of the NBR ISO 5008 wheels and field machines - (measurement of the vibration transmitted to the operator's whole body) which specifies the measurements on the agricultural tractors (ABNT, 2015).

Using a knob, the seat had been adjusted by changing the seat stiffness to suit the mass of the operator $(95 \mathrm{~kg})$. The following values were recorded for the $\mathrm{X}$ axis, $73 \%$ for the $\mathrm{Y}$ axis and $80 \%$ for the $\mathrm{Z}$ axis.

Once the field-testing was done the operator's whole body vibration (WBV) was measured using the DELTA OHM ${ }^{\circledR}$ HD 2030 vibration meter. A triaxial seat accelerometer model 356B41 from the same manufacturer was connected to the vibration meter.

During the test, the accelerometer was fixed to the seat base using adhesive tape, so that it remained in the same position throughout. The accelerometer was placed near the seat center, in such a way that the operator's coccyx coincided with the center of the seat pad for 180 -sec and the readings were noted.

To evaluate the vibration the values of RANE (Resultant Acceleration of Normalized Exposure) and RVDV (Resultant Vibration Dosing Value) were assessed. Values were calculated by considering a daily 8-hour working day, with the tractor performing only a single operation throughout the whole day, with reference to only one exposure component.

According to ANNEX VIII of NR-15 Activities and Unhealthy Operations (BRASIL, 2014) the condition is considered unhealthy if any of the limits of daily occupational exposure to WBV are surpassed:

(a) the acceleration value calculated from the standardized exposure (RANE) of $1.1 \mathrm{~m} . \mathrm{s}^{-2}$;

(b) the value of the resulting vibration dose (RVDV) of $21.0 \mathrm{~m} \cdot \mathrm{s}^{-1.75}$.

Many methods are available to evaluate the vibrations incident to the operator by the agricultural tractor; however, several of them evaluate the tractor alone. For instance, the NBR ISO 5008 (ABNT, 2015) includes, in Annex A, provision for field trials which can be attached to the tractor equipment. However, this norm and others connected to the assessment of occupational vibration do not include ways to evaluate the quantity of vibration that the attached equipment transmits to the operator.

Based on this assumption, we attempted in this study, to develop an index, which can stipulate the vibration that arises from the attached equipment alone. To confirm if, during the operation of equipment coupled to the tractor, the use of it attenuated or amplified the magnitude of vibrations incident to the operator, an index was developed. Equation 1 reveals the index of amplitude of the vibration incident to the operator by the agricultural equipment coupled to the tractor.

$I A V E A=\frac{V D V_{e q}}{V D V_{t}} \times 100$

Where,

IAVEA - Index of amplitude of vibration incident to the operator of the agricultural equipment attached to the tractor $(\%)$;

VDVeq - vibration dose value of the $\mathrm{X}, \mathrm{Y}$ or $\mathrm{Z}$ axes on the seat, with the equipment coupled to agricultural tractor $\left(\mathrm{m} . \mathrm{s}^{-1.75}\right)$.

VDVt - vibration dose value of the $\mathrm{X}, \mathrm{Y}$ or $\mathrm{Z}$ axes on the seat, without the equipment coupled to agricultural tractor $\left(\mathrm{m} . \mathrm{s}^{-1.75}\right)$.

For all the operations performed, the completely random experimental design was selected. Comparisons were done of the operations with each other, with five mechanized sets and the tractor without any coupled equipment, at two tractor travel speeds of $3.4 \mathrm{~km} \cdot \mathrm{h}^{-1}$ and $6.1 \mathrm{~km} \cdot \mathrm{h}^{-1}$.

The equipment used collected data every $1 \mathrm{~s}$, for each repetition performed, measurements were taken of $180 \mathrm{~s}$, for 180 samples in total for each repetition. Five replications were done for each treatment.

The data obtained using the vibration meter were processed by the Noise Studio ${ }^{\circledR}$ software 6.95. The data were statistically evaluated using 
the statistical program ASSISTAT version 7.7 beta (SILVA \& AZEVEDO, 2016). Normality of the data was verified by submitting them to the AndersonDarling test. All the variables evaluated could be verified to have normal distribution by the AndersonDarling test at the 5\% level of significance.

After confirming the normality, the data were submitted to the analysis of variance by the $\mathrm{F}$ test, and when significant, the means were compared by the Tukey test, at the $5 \%$ level of significance.

\section{RESULTS AND DISCUSSION}

Tables 1 and 2 list the mean values obtained for Standardized Exposure Acceleration (RANE) and the Resulting Vibration Dose Value (RVDV).

The RVDV represents the cumulative exposure to the vibrations in a working day, obtained from the three orthogonal axes $\mathrm{X}, \mathrm{Y}$ and $\mathrm{Z}$. This is the most suitable method of assessing the effect of vibration exposure on workdays extending beyond 8 hours because it represents more of the bumps and shocks that occur during the operation (SCARLETT et al. 2007).

According to Brazilian legislation, the recommendation of the NR-15 (BRASIL, 2014) to characterize the unhealthy working conditions is to verify the evaluation of the two parameters at the same time as the RANE and RVDV.

For the $3.5 \mathrm{~km} \cdot \mathrm{h}^{-1}$ speed, it is evident that the tractor without the attached equipment and the sets tractor-moldboard plow, tractor-scarifier and tractor-rotary hoe had RANE values below $0.5 \mathrm{~ms}^{-2}$ and RVDV values below $9.0 \mathrm{~ms}^{-1.75}$. This implies that they come under the acceptable condition; therefore, according to the NHO-09 (FUNDACENTRO, 2013), one should maintain at least the existing condition.

According to the NHO-09 (FUNDACENTRO, 2013), even when the RANE or RVDV values are obtained in the acceptable condition, adoption of steps to lower the exposure levels, if available or viable, should be considered because it enhances the exposure conditions and reduces the health risks.

The sets tractor-disk plough and tractor-offset disc harrow at $3.5 \mathrm{~km} \cdot \mathrm{h}^{-1}$ speed obtained RANE values in the range of $>0.5$ to $<0.9 \mathrm{~ms}^{-2}$ and RVDV values in the range of $9.1>$ to $<16.4 \mathrm{~ms}^{-1.75}$, implying that they fall into the condition above the action level. Therefore, according to the NHO-09 (FUNDACENTRO, 2013), at least preventive measures must be undertaken to minimize the exposure of the operator to vibration.

Table 1 - The Resultant Acceleration of Normalized Exposure - RANE (m. $\mathrm{s}^{-2}$ ) and Resultant Vibration Dosing Value - RVDV (m.s ${ }^{-1.75}$ ) values obtained with the tractor operating without equipment and with different mechanized sets with displacement velocity of $3.5 \mathrm{~km} \cdot \mathrm{h}^{-1}$.

\begin{tabular}{|c|c|c|}
\hline Sources of Variation & $\operatorname{RANE}\left(\mathrm{m} \cdot \mathrm{s}^{-2}\right)$ & $\operatorname{RVDV}\left(\mathrm{m} \cdot \mathrm{s}^{-1,75}\right)$ \\
\hline Tractor (Control T.) & $0.396^{\mathrm{c}}$ & $7.979^{\mathrm{c}}$ \\
\hline Tractor-moldboard plow set & $0.418^{\mathrm{c}}$ & $8.285^{\mathrm{c}}$ \\
\hline Tractor-disk plough set & $0.794^{\mathrm{a}}$ & $15.158^{\mathrm{a}}$ \\
\hline Tractor-scarifier set & $0.434^{\mathrm{c}}$ & $8.481^{\mathrm{c}}$ \\
\hline Tractor-offset disc harrow set & $0.662^{\mathrm{b}}$ & $12.643^{\mathrm{b}}$ \\
\hline Tractor-rotary hoe set & $0.434^{\mathrm{c}}$ & $9.044^{\mathrm{c}}$ \\
\hline Tests F & RANE $\left(\mathrm{m} \cdot \mathrm{s}^{-2}\right)$ & $\operatorname{RVDV}\left(\mathrm{m} \cdot \mathrm{s}^{-1,75}\right)$ \\
\hline Treatments $(\mathrm{F})$ & $57.6360^{* *}$ & $60.8141^{* *}$ \\
\hline F-crit. & 3.8951 & 3.8951 \\
\hline CV $(\%)$ & 9.19 & 8.15 \\
\hline DMS & 0.094 & 1.641 \\
\hline Anderson-Darling test & $\operatorname{RANE}\left(\mathrm{m} \cdot \mathrm{s}^{-2}\right)$ & $\operatorname{RVDV}\left(\mathrm{m} . \mathrm{s}^{-1.75}\right)$ \\
\hline Obtained value & 0.68246 & 0.68766 \\
\hline V crit. & 0.71186 & 0.71186 \\
\hline Normal & Yes & Yes \\
\hline
\end{tabular}

Legend: Means followed by the same lower case letter do not differ by Tukey test $(\mathrm{p} \leq 0.05)$. ${ }^{*}$ Significant by $\mathrm{F}$ test at the $5 \%$ probability level. ${ }^{* *}$ Significant by $\mathrm{F}$ test at the $1 \%$ probability level. ns: not significant by the $\mathrm{F}$ test at the 5\% probability level. DMS: minimum significant difference. CV: coefficient of variation. Source: Prepared by the Author (2019). 
Table 2 - The Resultant Acceleration of Normalized Exposure - RANE (m. $\mathrm{s}^{-2}$ ) and Resultant Vibration Dosing Value - RVDV (m. $\mathrm{s}^{-1.75}$ ) recorded with the tractor operating without equipment and with different machined sets with displacement speed of $6.1 \mathrm{~km} . \mathrm{h}^{-1}$.

\begin{tabular}{|c|c|c|}
\hline Sources of Variation & $\operatorname{RANE}\left(\mathrm{m} \cdot \mathrm{s}^{-2}\right)$ & $\operatorname{RVDV}\left(\mathrm{m} . \mathrm{s}^{-1.75}\right)$ \\
\hline Tractor (Control T.) & $0.485^{\mathrm{d}}$ & $9.042^{\mathrm{d}}$ \\
\hline Tractor-moldboard plow set & $0.664^{\mathrm{c}}$ & $12.676^{\mathrm{c}}$ \\
\hline Tractor-disk plough set & $1.11^{\mathrm{a}}$ & $21.203^{\mathrm{a}}$ \\
\hline Tractor-scarifier set & $0.743^{\mathrm{bc}}$ & $14.194^{\mathrm{bc}}$ \\
\hline Tractor-offset disc harrow set & $0.998^{\mathrm{a}}$ & $19.026^{\mathrm{a}}$ \\
\hline Tractor-rotary hoe set & $0.858^{\mathrm{b}}$ & $16.388^{\mathrm{b}}$ \\
\hline Tests F & $\operatorname{RANE}\left(\mathrm{m} . \mathrm{s}^{-2}\right)$ & $\operatorname{RVDV}\left(\mathrm{m} . \mathrm{s}^{-1.75}\right)$ \\
\hline Treatments $(\mathrm{F})$ & $56.4735^{* *}$ & $59.1231^{* *}$ \\
\hline F-crit. & 3.8951 & 3.8951 \\
\hline $\mathrm{CV}(\%)$ & 9.19 & 7.51 \\
\hline DMS & 0.116 & 2.225 \\
\hline Anderson-Darling test & $\operatorname{RANE}\left(\mathrm{m} \cdot \mathrm{s}^{-2}\right)$ & $\operatorname{RVDV}\left(\mathrm{m} . \mathrm{s}^{-1.75}\right)$ \\
\hline Obtained value & 0.42532 & 0.44544 \\
\hline V crit. & 0.71186 & 0.71186 \\
\hline Normal & Yes & Yes \\
\hline
\end{tabular}

Legend: Means followed by the same lower case letter do not differ by Tukey test ( $\leq \leq 0.05)$. "Significant by $\mathrm{F}$ test at the $5 \%$ probability level. ${ }^{* *}$ Significant by $\mathrm{F}$ test at the $1 \%$ probability level. ns: not significant by the $\mathrm{F}$ test at the $5 \%$ probability level. DMS: minimum significant difference. CV: coefficient of variation. Source: Prepared by the Author (2019).

According to the NHO-09 (FUNDACENTRO, 2013) preventive steps are measures that have a propensity to reduce the likelihood that the exposure the operator experiences to the vibration will be detrimental to him and ensure that the limit of exposure is not surpassed. Measures employed should warrant periodic exposure monitoring, operator guidance (exposure risks, postexposure care like circumventing lifting and avoiding twisting and bending movements) and medical monitoring.

Regarding the agricultural machinery operators, preventive measures must be ensured, such as adopting appropriate operation speeds but which will also have lower vibration levels, monitoring if the adjustment of agricultural equipment is correct and fine-tuning the tractor seat in terms of positioning and operator bodyweight.

Only at the tractor displacement speed of $6.1 \mathrm{~km} \cdot \mathrm{h}^{-1}$, when no equipment was attached, the acceptable condition was achieved. Sets tractormoldboard plow, tractor-scarifier and tractor-rotary hoe surpassed the condition above the level of action, and preventive measures were mandatory to decrease the degree of operator exposure.

Tractor-offset disc harrow set showed RANE values in the range of 0.9 to $1.1 \mathrm{~m} \cdot \mathrm{s}^{-2}$ and
RVDV in the range of 16.4 to $21 \mathrm{~m} . \mathrm{s}^{-1.7}$, reaching the uncertainty region condition.

The NHO-09 (FUNDACENTRO, 2013) stated that when the region of uncertainty is reached, preventive and corrective measures are mandatory to mitigate the daily exposure of the operator to vibration.

According to the definition of the NHO-09 (FUNDACENTRO, 2013), the corrective measures included the following: decreased working hours, work routine changes (doing other functions that do not require the tractor to lower the daily exposure dosage), the adoption of anti-vibrator seats, (improper maintenance can intensify the vibrations arising from the machine), modification of the tire calibration, usage of suspension systems (practically non-existent in tractors marketed in Brazil), and alterations in the operating platform etc. The tractor-disk plough set obtained RANE values above $1.1 \mathrm{~m} \cdot \mathrm{s}^{-2}$ and RVDV values exceeding $21 \mathrm{~m} \cdot \mathrm{s}^{-1.75}$, achieving the state of surpassing the exposure limit.

The NHO-09 (FUNDACENTRO, 2013) stated that if the exposure limit is exceeded, corrective measures must be taken at once to lower the vibration levels.

GOGLIA et al. (2003) proposed that the foremost and fastest method of minimizing health 
risks arising from exposure to occupational vibration is to reduce the exposure time by redistributing the operators to other functions that are not linked to the vibration through their entire working day.

FUTATSUKA et al. (1998) also identified unhealthy working conditions in an 8-hour workday. They suggested that the best way to mitigate operator health risk was by providing new suspension mechanisms on the present agricultural tractors, in order to be able to decrease exposure to occupational vibration.

MARSILI et al. (2002) demonstrated that the inclusion of suspension systems on tractors could induce more than $50 \%$ escalation of the operator exposure time without causing additional health damage.

BALBINOT \& TAMAGNA (2002) proposed that RVDV values exceeding $8.5 \mathrm{~m} \mathrm{~s}^{-1.75}$ would cause operator discomfort. The present research revealed displacement velocity values of 3.5 $\mathrm{km} . \mathrm{h}^{-1}$ with higher values obtained for the sets tractordisk plough, tractor-rotary hoe and tractor-offset disc harrow, while for the $6.1 \mathrm{~km} \cdot \mathrm{h}^{-1}$ speed all the sets showed higher values. Incidentally, the author stated that values exceeding $15 \mathrm{~m} \cdot \mathrm{s}^{-1.75}$ can induce severe discomfort and the onset of pain, primarily in the lower back. At the $3.5 \mathrm{~km} . \mathrm{h}^{-1}$ speed, the tractor-disk plough set assembly achieved higher values, while for the $6.1 \mathrm{~km} . \mathrm{h}^{-1}$ speed, the sets tractor-disk plough, tractor-rotary hoe and tractor-offset disc harrow surpassed the $15 \mathrm{~ms}^{-1.75}$, implying the likelihood of the onset of occupational diseases to the operator.

For CUNHA et al. (2012) occupational vibration issues can be attenuated by decreasing the intensity of the vibrations at its source along with decreasing the time of exposure to the vibration. To mitigate this vibration, it becomes crucial to know the reality of the country, the equipment commercialized there, before formulating tactics to minimize these vibrations.

ZEHSAZ et al. (2011) stated that for economic reasons tractors lacking cabin and seat suspension systems are in greater demand, which is the reason that manufacturers have resolved to supply basic tractors without these systems.

Tables 3 and 4 show the results of the $F$ test and the mean IAVEA\% values for the mechanized assemblies assessed on the $\mathrm{X}, \mathrm{Y}$ and $\mathrm{Z}$ axes. Scarlet et al., (2007) in their evaluation of the whole-body occupational vibrations in mechanized assemblies

Table 3 - Index of amplitude of vibration incident to the operator of the agricultural equipment attached to the tractor - IAVEA values $(\%)$ in the $\mathrm{X}, \mathrm{Y}$, and $\mathrm{Z}$ axes obtained with the different machined sets with displacement velocity of $3.5 \mathrm{~km} . \mathrm{h}^{-1}$.

\begin{tabular}{|c|c|c|c|}
\hline Sources of Variation & $\begin{array}{c}\text { IAVEA (\%) } \\
\text { X axis }\end{array}$ & $\begin{array}{c}\text { IAVEA (\%) } \\
\text { Y axis }\end{array}$ & $\begin{array}{c}\text { IAVEA (\%) } \\
Z \text { axis }\end{array}$ \\
\hline Tractor-moldboard plow set & $127.5 \mathrm{~b}$ & $132.1 \mathrm{a}$ & $116.3 b$ \\
\hline Tractor-disk plough set & $217.8 \mathrm{a}$ & $152.9 \mathrm{a}$ & $195.4 \mathrm{a}$ \\
\hline Tractor-scarifier set & $127.6 \mathrm{~b}$ & $133.9 \mathrm{a}$ & $125.8 b$ \\
\hline Tractor-offset disc harrow set & $149.5 \mathrm{ab}$ & $139.1 \mathrm{a}$ & $117.1 \mathrm{~b}$ \\
\hline Tractor-rotary hoe set & $135.5 b$ & $141.4 \mathrm{a}$ & $121.6 \mathrm{~b}$ \\
\hline Sources of Variation & $\begin{array}{c}\text { IAVEA (\%) } \\
\text { X axis }\end{array}$ & $\begin{array}{c}\text { IAVEA }(\%) \\
\text { Y axis }\end{array}$ & $\begin{array}{c}\text { IAVEA (\%) } \\
Z \text { axis }\end{array}$ \\
\hline Treatments (F) & $3.9611^{*}$ & $0.5157 \mathrm{~ns}$ & $86.9966^{* *}$ \\
\hline F-crit. & 2.8861 & 0.117 & 4.4307 \\
\hline $\mathrm{CV}(\%)$ & 28.23 & 18.28 & 6.00 \\
\hline DMS & 81.2 & 48.48 & 15.38 \\
\hline Anderson-Darling test & $\begin{array}{c}\text { IAVEA (\%) } \\
\text { X axis }\end{array}$ & $\begin{array}{c}\text { IAVEA }(\%) \\
\text { Y axis }\end{array}$ & $\begin{array}{c}\text { IAVEA (\%) } \\
Z \text { axis }\end{array}$ \\
\hline Obtained value & 0.51114 & 0.45317 & 0.33770 \\
\hline V crit. & 0.70268 & 0.70268 & 0.70268 \\
\hline Normal & Yes & Yes & Yes \\
\hline
\end{tabular}

Legend: Means followed by the same lower case letter do not differ by Tukey test ( $\mathrm{p} \leq 0.05)$. ${ }^{*}$ Significant by F test at the $5 \%$ probability level. ${ }^{* *}$ Significant by $\mathrm{F}$ test at the $1 \%$ probability level. ns: not significant by the $\mathrm{F}$ test at the $5 \%$ probability level. DMS: minimum significant difference. CV: coefficient of variation. Source: Prepared by the Author (2019). 
Table 4 - Index of amplitude of vibration incident to the operator of the agricultural equipment attached to the tractor - IAVEA values $(\%)$ in the $\mathrm{X}, \mathrm{Y}$, and $\mathrm{Z}$ axes obtained with different machined sets having a displacement velocity of $6.1 \mathrm{~km} . \mathrm{h}^{-1}$.

\begin{tabular}{|c|c|c|c|}
\hline \multirow{2}{*}{ Observed Parameters } & IAVEA (\%) & IAVEA (\%) & IAVEA (\%) \\
\hline & $\mathrm{X}$ axis & $\mathrm{Y}$ axis & $\mathrm{Z}$ axis \\
\hline Tractor-moldboard plow set & $144.9^{\mathrm{bc}}$ & $133.9^{\mathrm{a}}$ & $134.9^{\mathrm{b}}$ \\
\hline Tractor-disk plough set & $263.9^{\mathrm{a}}$ & $189.9^{\mathrm{a}}$ & $242.44^{\mathrm{a}}$ \\
\hline Tractor-scarifier set & $143.3^{\mathrm{c}}$ & $153.6^{\mathrm{a}}$ & $156.9^{\mathrm{b}}$ \\
\hline Tractor-offset disc harrow set & $181.8^{\mathrm{b}}$ & $143.7^{\mathrm{a}}$ & $145.25^{\mathrm{b}}$ \\
\hline Tractor-rotary hoe set & $159.2^{\mathrm{bc}}$ & $145.8^{\mathrm{a}}$ & $142.73^{b}$ \\
\hline Sources of Variation & $\begin{array}{c}\text { IAVEA }(\%) \\
\text { X axis }\end{array}$ & $\begin{array}{c}\text { IAVEA }(\%) \\
\text { Y axis }\end{array}$ & $\begin{array}{c}\text { IAVEA }(\%) \\
Z \text { axis }\end{array}$ \\
\hline Treatments $(\mathrm{F})$ & $30.8413^{* *}$ & $2.1561^{\mathrm{ns}}$ & $7.7212^{* *}$ \\
\hline F-crit. & 4.4307 & 2.8861 & 4.4307 \\
\hline $\mathrm{CV}(\%)$ & 11.30 & 21.44 & 21.67 \\
\hline DMS & 38.3 & 62.35 & 67.59 \\
\hline Anderson-Darling test & $\begin{array}{c}\text { IAVEA }(\%) \\
\text { X axis }\end{array}$ & $\begin{array}{c}\text { IAVEA }(\%) \\
\text { Y axis }\end{array}$ & $\begin{array}{c}\text { IAVEA }(\%) \\
Z \text { axis }\end{array}$ \\
\hline Obtained value & 0.55910 & 0.61610 & 0.70056 \\
\hline $\mathrm{V}$ crit. & 0.70268 & 0.70268 & 0.70268 \\
\hline Normal & Sim & Sim & Sim \\
\hline
\end{tabular}

Legend: Means followed by the same lower case letter do not differ by Tukey test $(\mathrm{p} \leq 0.05)$. ${ }^{*}$ Significant by $\mathrm{F}$ test at the $5 \%$ probability level. ${ }^{* *}$ Significant by $\mathrm{F}$ test at the $1 \%$ probability level. ns: not significant by the $\mathrm{F}$ test at the $5 \%$ probability level. DMS: minimum significant difference. CV: coefficient of variation. Source: Prepared by the Author (2019).

indicated that the vibration intensity is directly related to the operation being performed, as well as to the agricultural equipment coupled to the tractor that is performing it.

Hence, a method that can assess individual agricultural equipment to identify its contribution to the system in terms of whether it has amplified or attenuated the vibrations incident to the operator is highly significant.

Thus, it can be considered that the same tractor can give different vibration values depending upon the agricultural equipment and the conditions of usage (slow moving, moving in operation, transport etc.) of the same, and the equipment may induce attenuation or amplification of the vibrations incident to the operator.

GOGLIA et al. (2003) proposed that for the same tractor, coupled to the same equipment, when the condition of use of the equipment alone is changed, a significant change in the vibration can be induced.

For instance, the transport condition is inclined to greatly intensify the vibrations for the mounted equipment because of the greater motion of the equipment when it is suspended by the hydraulic lift system, particularly in the $\mathrm{Y}$ axis.
All the mechanized assemblies assessed revealed amplification in all the three axes, $\mathrm{X}, \mathrm{Y}$ and $\mathrm{Z}$. It can be observed that the amplification levels increase as the speed of the tractor movement increases.

Tractor-moldboard plow set for the $3.5 \mathrm{~km} \cdot \mathrm{h}^{-1}$ tractor displacement speed produced $27.5 \%$ amplification for the $\mathrm{X}$ axis, $32.1 \%$ for the $\mathrm{Y}$ axis and $16.3 \%$ for the $\mathrm{Z}$ axis. This was the set showing the lowest amplification among the ones evaluated for the three orthogonal axes X, Y and Z for both displacement speeds used for the tractor. The $\mathrm{Y}$ axis showed practically no increase in the vibrations corresponding to the increase in the displacement speed.

SCARLET et al. (2007) in their estimation of the vibrations incident to the operator in mechanized assemblies (sprayer, moldboard plow and cultivator), revealed that the soil preparation equipment has the propensity to intensify the vibration levels, with the moldboard plow and the cultivator showing higher values than the sprayer.

Tractor-disk plough set showed amplification of the incident vibration for all the three orthogonal axes X, Y and Z, in which for the tractor displacement speed of $3.5 \mathrm{~km} \cdot \mathrm{h}^{-1}$ the $\mathrm{X}$ axis showed 
amplification of $117.8 \%$. The $\mathrm{Y}$ axis showed $52.9 \%$ and the $\mathrm{Z}$ axis showed $95.4 \%$. These are the highest recorded values. When the speed was increased to 6.1 $\mathrm{km} \cdot \mathrm{h}^{-1}$ an even higher amplification was noted, which exceeded that of the other equipment.

For the $3.5 \mathrm{~km} \cdot \mathrm{h}^{-1}$ tractor displacement speed, all the mechanized assemblies assessed, barring the tractor- disk plough set, revealed statistically equal amplification for all three orthogonal axes X, $\mathrm{Y}$ and $\mathrm{Z}$. Assemblages evaluated showed similar amplification, increased values for the $\mathrm{Z}$ axis and closer values ones for the $\mathrm{X}$ and $\mathrm{Y}$ axes.

For the displacement velocity of the tractor at $6.1 \mathrm{~km} \cdot \mathrm{h}^{-1}$, it is clear that for the $\mathrm{Y}$ axis no differences were evident among the treatments assessed, the only differences being restricted to the $\mathrm{X}$ and $\mathrm{Z}$ axes. The tractor-disk plough set showed the highest amplification levels.

\section{CONCLUSION}

All sets utilized revealed an increase in the whole body vibrations incident to the operator.

Under the conditions assessed, the tractordisk plough set revealed the highest vibration intensity accompanied by the higher risk of damage to the operator's health, for an 8-hour workday.

Under the conditions of the evaluation, the tractor-moldboard plow set presented the least amplification of the vibrations and health risks for an 8 -hour workday.

Thus, the IAVEA proved to be a reliable index that could quantify the amplification or attenuation caused by the use of agricultural equipment.

\section{ACKNOWLEDGMENTS}

This research was carried out with the support of the Higher Education Personnel Improvement Coordination - Brazil (CAPES) - Financing Code 001 and the Cearense Foundation for Supporting Scientific and Technological Development (FUNCAP).

\section{DECLARATION OF CONFLICT OF INTERESTS}

The authors declare no conflict of interest. The founding sponsors had no role in the design of the study; in the collection, analyses, or interpretation of data; in the writing of the manuscript, and in the decision to publish the results.

\section{AUTHORS' CONTRIBUTIONS}

All authors contributed equally for the conception and writing of the manuscript. All authors critically revised the manuscript and approved of the final version.

\section{REFERENCES}

ASSOCIAÇÃO BRASILEIRA DE NORMAS TÉCNICAS. NBR ISO 5008: Tratores agrícolas de rodas e máquinas de campo Medição da vibração transmitida ao corpo inteiro do operador. 18 p. 2015.

ASAE EP 496.2 DEC98. Agricultural Machinery Management. In: ASAE Standards: standards engineering practices data. St. Joseph: American Society of Agricultural Engineers, p. 353-358, 1999.

BAESSO, M. M. et al. Noise level evaluation, items security and ergonomic in agricultural tractors. Revista Brasileira de Engenharia de Biossistemas, v.9, n.4, p.368-380, 2015. Available from: <http://seer.tupa.unesp.br/index.php/BIOENG/ article/view/333>. Accessed: Jan. 20, 2018. doi: 10.18011/ bioeng2015v9n4p368-380.

BRASIL. Ministério do Trabalho. Portaria MTE n. ${ }^{0}$ 1.297, de 13 de agosto de 2014. NR 15 - anexo 08. Available from: <http:// www.guiatrabalhista.com.br/legislacao/nr/nr15.htm>. Accessed: Mar. 14, 2018

BALBINOT, A.; TAMAGNA, A. Evaluation of the transmissibility of the vibration in seats of bus drivers: a focus on comfort and health. Brazilian Journal of Biomedical Enginnering, v.18, n.1, p.31-38, Jan/Abr, 2002. Available from: <https://rbejournal. org/journal/rbejournal/article/5889fb $765 \mathrm{~d} 01231 \mathrm{a} 018 \mathrm{~b} 463 \mathrm{c}>$. Accessed: Dec. 30, 2018.

CUNHA, J. P. A. R. et al. Vibração e ruído emitidos por dois tratores agrícolas. Idesia, v.30, n.1, p.25-34. 2012. Available from: $<$ https://scielo.conicyt.cl/pdf/idesia/v30n1/art04.pdf $>$. Accessed: Dec. 22, 2018. doi: 10.4067/S0718-34292012000100004.

FIGUEIREDO, M. A. M. et al. Transporte coletivo: vibração de corpo-inteiro e conforto de passageiros, motoristas e cobradores. Journal of Transport Literature, v.10, n.1, p.35-39, Jan. 2016. Available from: <http://www.scielo.br/pdf/jtl/v10n1/2238-1031jtl-10-01-0035.pdf>. Accessed: Jan. 10, 2017. doi: 10.1590/22381031.jt1.v10n1a7.

FUNDACENTRO. Norma de higiene ocupacional (NHO-09): Avaliação da exposição ocupacional a vibrações de corpo inteiro: procedimento técnico. São Paulo: Fundacentro, 2013. Available from: <http://www.fundacentro.gov.br/biblioteca/ normas-de-higiene-ocupacional/publicacao/detalhe/2013/4/nho09-procedimento-tecnico-avaliacao-da-exposicao-ocupacional-avibracao-de-corpo-inteiro>. Accessed: Dec. 06, 2018.

FUTATSUKA, M. et al. Whole-body vibration and health effects in the agricultural machinery drivers. Industrial Health, v.36, p.127-132， 1998. Available from: <http://joi.jlc.jst.go.jp/JST. Journalarchive/indhealth1963/36.127?from=PubMed $>$. Accessed: Dec. 19, 2018. doi: $10.2486 /$ indhealth.36.127.

GOGLIA, V. et al. Hand-transmitted vibration from the steering wheel to drivers of a small four-wheel drive tractor. Applied Ergonomics, v.34, p.45-49, 2003. Available from: <https://www.sciencedirect. com/science/article/pii/S0003687002000765?via\%3Dihub $>$. Accessed: May, 13, 2017. doi: 10.1016/S0003-6870(02)00076-5.

INTERNATIONAL ORGANIZATION FOR STANDARDIZATION. ISO 2631 Mechanical Vibration and Shock - Evaluation of Human Exposure of Whole- Body Vibration: General requirements. Genebra, 1997. 
LANGER, T. H. et al. Reducing whole-body vibration exposure in backhoe loaders by education of operators. Int. J. Ind. Ergon., v.42, p.304-311, 2012. Available from: <http://dx.doi. org/10.1016/j.ergon.2012.03.00>. Accessed: Dec. 14, 2016. doi: 10.1016/j.ergon.2012.03.00.

MACEDO, D. X. S, et al. Operational performance of a tractorseeder according to the velocity and working depth. Revista Brasileira de Engenharia Agrícola e Ambiental, Campina Grande, v.20, p.280-285, 2016. Available from: <http://www. agriambi.com.br/revista/v20n03/v20n03a14.pdf $>$. Accessed: Dec. 30, 2016. doi: 10.1590/1807-1929/agriambi.v20n3p280-285.

MARSILI, A. et al. Innovative systems to reduce vibrations on agricultural tractors: comparative analysis of acceleration transmitted through the driving seat. Biosystems Engineering, v.81, p.35-47, 2002. Available from: <https://www.sciencedirect com/science/article/pii/S1537511001900030>. Accessed: Dec. 30, 2018. doi: 10.1006/bioe.2001.0003.

PALMER, K. T. et al. Case-control study of low-back pain referred for magnetic resonance imaging, with special focus on wholebody vibration. Scand. J. Work Environ. Health, v.34, p.364373, 2008. Available from: <https:/www.ncbi.nlm.nih.gov/ pmc/articles/PMC2875180/>. Accessed: Mar. 11, 2018. doi: 10.5271/sjweh. 1282 .
SANDI, J. et al. Vibração mecânica em um trator agrícola ensaiado em pista padronizada. Energia na Agricultura, Botucatu, v.31, n.3, 2016. Available from: <http://revistas.fca.unesp.br/index. php/energia/article/view/2246>. Accessed: Apr. 16, 2018. doi: 10.17224/EnergAgric.2016v31n3p215-222.

SCARLETT, A. J. et al. Whole-body vibration: evaluation of emission and exposure levels arising from agricultural tractors. Journal of Terramechanics, v.44, p.65-73, 2007. Available from: <https://www.sciencedirect.com/science/ article/abs/pii/S0022489806000085>. Accessed: May, 16, 2018. doi: 10.1016/j.jterra.2006.01.006.

SILVA, F. de A. S. e.; AZEVEDO, C. A. V. de. The Assistat Software Version 7.7 and its use in the analysis of experimental data. Afr. J. Agric. Res., v.11, n.39, p.3733-3740, 2016. Available from: <https://academicjournals.org/journal/AJAR/ article-full-text-pdf/5E8596460818>. Accessed: Apr. 13, 2017. doi: 10.5897/ajar2016.11522.

ZEHSAZ, M. et al. Tractor cabin's passive suspension parameters optimization via experimental and numerical methods. Journal of Terramechanics, Amsterdã, v.48, p.439450, 2011. Available from: <https://www.sciencedirect.com/ science/article/abs/pii/S0022489811000632>. Accessed: May, 14, 2018. doi: 10.1016/j.jterra.2011.09.005. 